\title{
Response by Linda McCall for the presentation of the 2020 Strimple Award of the Paleontological Society
}

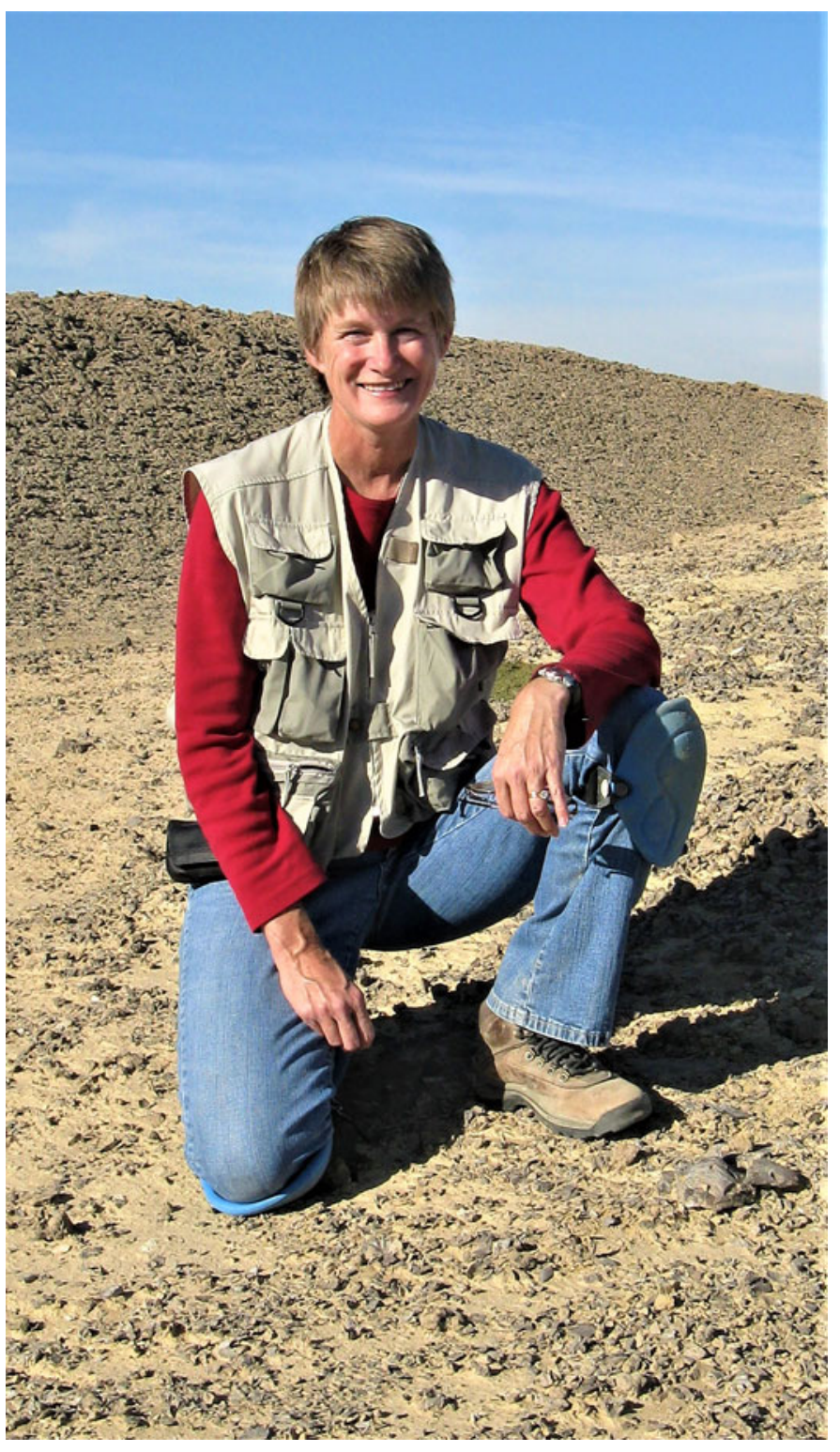

Paleontology has been my passion for most of my life. Receiving the Strimple Award is the highest recognition an amateur paleontologist can receive, and the highlight of my paleontological life to date. That is not lost on me. Nor is the fact that I am the first stand-alone woman to receive it. My most sincere thanks go out to Jen Bauer for nominating me this cycle and to Dr. Jim Sprinkle for nominating me so many times before. Without their perseverance and steadfast belief in me and, I would not be here today.
Many people have helped me along the way. My love of science I owe to my mother, who as a chemistry major in the mid-1940s, was WAY ahead of her time. She never tired of patiently identifying the broken bits of crinoids and brachiopods I would bring her from our church parking lot, and explained in detail how it used to be an ocean long, long ago. I grew up with a holistic love for nature and all things science. The tenacity comes from my father...But growing up in the $60 \mathrm{~s}$ and $70 \mathrm{~s}$ as a science loving girl had its issues. There was a lot of conflicting messaging. Initially I wanted to be a jet fighter pilot like my father when I grew up, and he had to break it to me that girls weren't allowed to do that, so I had to come up with something else.

Moving to Texas when I was 12 solidified my passion for paleontology. Fossils were EVERYWHERE, and I spent all my spare time riding my bike to nearby outcrops and collecting fossils. In high school, my science teachers were super supportive and encouraging and I owe them an immense debt of gratitude for believing in a girl who dreamed of growing up to be a paleontologist. I would give presentations to my classmates and set up fossil displays in the school library and didn't even mind it when my peers called me "brainy" or "geeky."

1975 and college at UT Austin started out well. As a freshman, I had the honor to be hired to work at the Balcones Research Center (now the J. J. Pickle Research Center) in the Vertebrate Paleo lab under Dr. Wann Langston and Dr. Ernie Lundelius. Rare for a freshman and super rare for a girl freshman. After an initial hazing, where I was sent to the "dark room" by Earl and Bob, and told to slip in the door in the dark, then feel on the wall for the switch which would be the right light to turn on and not ruin the film being developed, they then waited until they heard the scream - because the "dark room" was in reality the "Bug Room" and when I turned around and saw all the rotting, bug covered carcasses draped everywhere, scream I did. Apparently they heard me 2 buildings away. Having deemed my scream acceptable I was allowed to join their ranks.

But, by my sophomore year, the school councilors made it clear that girls didn't get to do fieldwork and the best I could hope for was a desk job looking at microbes for an oil and gas company somewhere. Not anything I was interested in-so I dropped out of school, got a job, married, had kids, and joined a fossil club to do paleontology on the side.

The fossil club was wonderful. Here were like- minded people— girls too, who all loved fossils as much as I did — and we frequently went out in the field collecting together and shared information and techniques. Here I met Don O'Neil, my mentor for many years, and one of the smartest self-taught paleontologists I have ever met. Dr. Jim Sprinkle was the club's science adviser, and in 1985 our group wrote a professional paper 
based in part on a specimen I had found while on a club trip to Oklahoma. I spent many happy years hanging with this group of folks while working my day job and raising 3 children.

Then, in 1994 I developed a severe case of CPTSD. I lost my job, my marriage, and my children. I couldn't work for 5 years. Those were some dark times. One of the only things I had left that I COULD do, was go out to the field and collect fossils. And collect I did. And slowly but surely, with a lot of hard work over many years (along with a rocking good therapist) I got better. I went back to work, regained my children, and met and married my super supportive husband. Today my condition is barely noticeable.

You will notice from my CV that almost everything listed on it has been from 2008 on, so basically I've done all that since I turned 50. Dr. Ann Molineux and Dr. Jim Sprinkle were kind enough to take me under their wing as I recovered and took the time to teach me the ropes on technical paper writing and doing conference presentations-how to push myself, do research, and try harder. Thanks to their patience, guidance, and mentoring, the dream I had as a little girl has found new life in an alternative reality. When amateurs and professionals work together, both benefit and he sum is far greater than the individual parts.

What I have learned over the course of my life is that it doesn't matter your age or your gender or even your disability. If you love something, let that passion be the light that guides you on your way to achieving your goals. In conclusion, I would like to thank the hundreds of people who have helped me along this journey and on behalf of all the women in paleontology and amateurs everywhere of every race, gender, color, or creed, I humbly accept this award. Thank you.

Mallard Ct. Reidsville, NC 27320 $<$ lndmccall02@yahoo.com> 